\title{
Private Prison Cells: The Dynamics and Variety of Ian McEwan's Space Concepts of the Postmodern Gothic
}

\author{
Alice Sukdolová \\ sukdolova@pf.jcu.cz
}

\begin{abstract}
The paper will examine the dynamics of changes in the concepts of spaces in the selected novels written by the contemporary British author Ian McEwan. It will define the role of representational spaces in McEwan's early novels (The Cement Garden, The Comfort of Strangers) and concentrate on the term of intense focalization in the author's recent novel Nutshell. The main aim of the paper is to trace the presence of the uncanny in McEwan's fictional spaces and explore the theme of space violation and disturbing human privacy within the closed space which points out to the genre of postmodern Gothic.

Keywords: Ian McEwan, postmodern chronotope, space violation, the uncanny, postmodern Gothic
\end{abstract}

\section{Introduction: Space Narrative}

In his Theory of Space in Narrative, Zoran distinguishes three levels of space in literature, the first one being the topographical level in which space functions as a static entity. Secondly, space in accordance with time implies the chronotopic level, it is the space dynamically imposed with events and movements, and thirdly, the space in literature functions on the textual level as the space imposed with verbal sign, it is the representational space which supplies the "reconstructed world" (Zoran 316).

As for the topographical level of fictional spaces, the text can express topographical structure employing direct description as well as other textual components, such as a dialogue or another form of the narrative (Zoran 316). Theoretically, within the narrative tradition of realism, it may allow us the creation of a topographical map ${ }^{1}$ including the spatial existence of characters. In McEwan's Comfort of Strangers (1981), it would have been possible to draw a map of Venice according to the movement of characters in particular streets, even though the name of the city is never mentioned directly. It should exist as a universal city which is subject

Cf. David Harvey's mental mapping in Harvey, Consciousness and the Urban Experience: Studies in the History and Theory of Capitalist Urbanization (Baltimore: The Johns Hopkins University Press, 1985), 13. 
to globalization and thus functions as a labyrinth of the characters' aimless movement. Hence, the topographical level does not play a crucial role in the postmodern spatial construct and the aim of this paper shifts towards the chronotopic and textual levels of analysis.

Secondly, in Zoran's structural theory, the chronotopic level of the text is to be considered. It is undoubtedly more productive to concentrate on the chronotope as Henri Lefebvre stated that we cannot rely on literature in terms of providing "true pictures" of the world (Lefebvre). Thus, the topographical level of the novel, especially in the postmodern sense, cannot be sufficient even within the poetics of realism. According to Paul Smethurst, the chronotope provides us with information "how an author has arranged representational space to convey conceptions and anxieties about space and time in society" (Smethurst 62). The paper will further concentrate on McEwan's anxiety in the space of his early novels, namely in the theme of violation of private space, human alienation, and isolation of particular characters. The aim is to examine the changes in McEwan's tone and poetics in the $21^{\text {st }}$ century in the context of the space analysis.

\section{Postmodern Space Representations}

Postmodern theories frequently focus on defining the notion of place in contrast with the definition of space. Space is understood as more abstract, it is the undifferentiated space with the potential to become a place as we experience it and endow it with value. Thus, the relation between a place and space may be described as dialectical, as a relation between presence and absence (Smethurst 55). "Place never has complete presence, both because it is always disappearing and being reproduced, and also because much of its presence is conditioned by representational spaces which are properly absent from concrete structures and spaces that constitute physical place" (Smethurst 55).

McEwan's use of representational spaces may be analyzed particularly in his early novels, The Cement Garden and The Comfort of Strangers. The house on the outskirts of a city in The Cement Garden occupied by four orphaned siblings, or a model city in The Comfort of Strangers become symbolic labyrinths of the postmodern civilization without any specific existential aim. According to K. Vránková, the house in The Cement Garden reflects "the emptiness of the future [...] caused by the ruin of social and family ties [...] representing a deep and passionate desire to defy the transitoriness of life by preserving the idealized and unchangeable image of childhood" (Vránková 2019, 127-8). Amsterdam as a place in the eponymous novel also functions as a representational model for the characters who in the final 
crucial scene visit a city hotel because they want to make use of the benevolent legal system of the country. In the grim and grotesque scene, the two former friends misuse the law which allows legal euthanasia and paradoxically enough they commit murder poisoning each other. The fictional setting of the Amsterdam hotel then becomes a representational place selected by the author due to its symbolic quality.

The postmodern chronotope in McEwan's novels thus functions as a form of Weltanschauung producing a time-space map of the contemporary world. In Solar, McEwan's 2010 novel, the variety of fictional settings becomes more globalized as the main protagonist travels worldwide for both professional and private reasons. The novel focuses on extreme contrasts as for the climate of the opening and final part, introducing the character in the first scene taking part in an Arctic expedition, and finding him on the verge of death of a heart attack in Mexico in the extremely hot climate of the last scene. The novel's focus on the environment points to the global world changes in the climate and reflects the character's crisis in the globalized world.

\section{The Violation of Private Space in the City}

Looking back at the history of space representations of the city in the course of the $20^{\text {th }}$ century, London indeed displays its modernist legacy, particularly in McEwan's novel Saturday, published in 2005. Taking place in just one day (and the dreadful night), it reflects the Woolfian heritage and mirrors Mrs Dalloway in several aspects. ${ }^{2}$ In spite of the modernist allusions in the space-time structure of the novel, Saturday is an expression of postmodern fear of potential dangers that lurk from London narrow streets and may terrify even the self-confident and relatively well-situated characters. Therefore, we can trace the presence of the uncanny in the novel. The crucial incidents of space violation happen either within Perowne's own private space of the house or in the neighbouring streets of his residence, the very first incident of the plane accident being witnessed by him directly from the window of his bedroom. Therefore, the line between his professional space of work in the hospital, the private space of his home residence, and public and social life in the street, is very thin and the public space seems to intrude into his privacy radically. The most serious incident, which starts in the street but is later shifted into Perowne's residence, affects the whole family and has its climax in the hospital,

2 Philip Tew analyzed the details of the comparison between Saturday and Mrs Dalloway in The Contemporary British Novel (2007). 
over the operation table where the main character faces a moral choice; either to let the criminal and the initiator of the brutal assault live or let him die. In comparison to other McEwan's characters of his novels, this moral choice is clear and the neurosurgeon has a chance to forgive his enemy and deserve his moral credit. ${ }^{3}$

As for the violation of the private space in McEwan's novels, the bedroom seems to be the place most exposed not only to perversion and macabre incidents (in The Cement Garden, The Comfort of Strangers) but it also reflects particular moments of the characters' existential crisis in their individual lives (Saturday, On Chesil Beach) or the critical moments of the lives' beginnings and ends (Nutshell). Thus, the private space of the bedroom points indirectly to the title of McEwan's early collection of short stories First Love, Last Rites (1975), and it expresses postmodern uncertainties and fear of the violation of privacy as the main themes of McEwan's novels.

According to Nora Pleßke ${ }^{4}$, public and private spheres of human life become permeable in the postmodern city, especially through the media. Such a notion may be reflected both in McEwan's Saturday and Nutshell. In the latter novel, the yet unborn hero constructs his idea of the outside world not only as he listens to his mother's voice and her dialogues with his father and with Claude, his uncle, but also as he perceives the noise of the city and overhears the radio news. His sarcastic comments on the world situation and contemporary society then become the source of humour and irony.

Nevertheless, the tone of the narrative in Saturday remains as serious as the main protagonist's profession. The climax of the novel is based on the interpenetration of "public drama into the private" (Pleßke 196) as the criminal assault of the neurosurgeon's patient affects the whole family, intruding into the party. ${ }^{5}$ Another aspect of the interpenetration of the public sphere into the private life of the characters of the novel is the confrontation of social classes. Henry Perowne becomes confronted with a criminal whom he offends and enters his private space, revealing Baxter's medical diagnosis and thus humiliating him. The consequent revenge of the criminal, i.e. his intrusion into Perowne's private residence, is of course an inappropriate reaction. However, Perowne, who had deliberately stressed his social status in the

3 In McEwan's other novels, Solar (2010) and Amsterdam (1998), the main protagonists, particularly the worldwide known scientist awarded Nobel Prize in physics and the editor and the music composer in Amsterdam, are not as gifted as far as their moral credit is concerned.

4 For more, see Nora Pleßke, The Intelligible Metropolis: Urban Mentality in Contemporary London Novels (Bielefeld: Transcript Verlag, 2014), 223.

5 The motif of organizing a party and the final climax where the protagonists of Saturday become exposed to a deadly threat contribute to the context of intertextual allusions the novel shares with Mrs Dalloway. 
car accident, became involved in more serious problems behaving condescendingly towards a person representing a lower social class. Moreover, Perowne indirectly expresses his contempt towards the crowd protesting in the square, again with the feeling of his social superiority. Thus, we may interpret the intrusion of the public sphere into the private one as a "moral lesson" for the neurosurgeon who becomes aware of his limits but also of his professional skills. In his professional sphere, he acts like someone who is morally strong and is finally able to forgive the criminal. He has to face the challenge not to succumb to the strange and possibly dangerous other, and defend the familiar space. Foucault considers the space between familiarity and strangeness as a heterotopian space of liminality ${ }^{6}$, which is the characteristic position the protagonist of the novel has to face in the climax of Saturday.

\section{McEwan's London and the Urban Experience}

For Henri Lefebvre, the starting point for the conceptualization of space is the lived experience of place. Nevertheless, spatial practices tend to become the subject of conceptual aestheticization, especially of the modern urban existence. More specifically in the case of the urban space representation, as David James points out, "fictional settings often coerce us to participate in the way spaces are perceived" (James 15). Hence, our image of the city is to some extent enriched by the creation of fictional spaces in spite of our lived experience.

According to the phenomenological theory of Merleau-Ponty ${ }^{7}$, the lived space and subjective existential experience related to a particular subject results in a form of psychological introspection and points out to the reflections about the self and the look within.

McEwan's 2016 novel Nutshell offers such introspection in an extreme example of the tight, enclosed, uncanny space of the mother's womb. The novel is set in a Georgian London house which, ironically, reflects the postmodern sense of human corruption, moral decay, and deterioration of a family. Nutshell is an allusion to "family relations" of a Shakespearean tragedy but it also points out criticism of contemporary materialism, the hunt for money and human cruelty accompanying the feeling of intensive physical passion and ignorance. The space of the novel can be understood and perceived by the reader in two ways. The "outside" world is,

6 For more, see Michel Foucault, "Of Other Spaces: Utopias and Heterotopias", trans. Jay Miskowiec. Architecture /Mouvement/ Continuité. no. 5(1984): 46-49.

7 For more, see Maurice Merleau-Ponty, Phenomenology of Perception (London and New York: Routledge, 1962). 
paradoxically, limited to the house interiors which are kept consistently unclean because of the mother's decision to ignore basic cleaning habits, resulting in omnipresent heaps of garbage around the house, rotten food, and massive dirt. The state of the household reminds the reader of McEwan's first crucial novel, The Cement Garden, in which the children's behaviour reflects a revolt against social norms and their paralysis after the parents' death. In Nutshell the mess becomes a symbol of the woman's omnipresent ignorance of her marriage and her social role of a to-be mother. The house is generally dilapidated for particular reasons as the lovers intricate the murder plot to get rid of the husband, the house owner. The first person narrator, however, projects the novel's perspective from the "inside" of his mother's womb: "So here I am, upside down in a woman. Arms patiently crossed, waiting, waiting and wondering who I'm in, what I'm in for." (Mc Ewan 2016, 1)

In Nutshell, the reader enters the essentially biological inner space of the yet unborn child, who, in many respects, resembles a little nameless Hamlet, and consequently witnesses the moments between the child's conception and his birth. From the psychological point of view, it is the space-time of being and becoming, a certain mode of the narrator's dream-time which depends intensively on his imagination of space perceived by other senses (the sense of hearing, tasting and possibly smelling things from the outside world). Symbolically, the space of the mother's womb represents a prison cell, an enclosed, tight space from which there is no escape. Therefore, the narrator's existence becomes extremely painful before he even enters the outside world. His desire is to be born, to act and prevent his father's murder. He calls for more space since the spatial limits of the womb become tragic before his birth and the lack of space for action frequently leads him to suicidal attempts. Though the situation seems to be hopeless and extremely dramatic, the reader can finally hope for a minimum level of justice as the child is born before the murderers can escape.

\section{Intense Focalization in Nutshell}

According to David James, McEwan's narrative technique is based on the "intensely focalized reception of distances and proximities, moment to moment [as] McEwan emphasizes these perspectival restrictions, conveying spectacular events by accreting successive details rather than intervening as a narrator. [...] McEwan shows us how space in the novel can rarely be dissociated from the artistry of narrative perception" (James 10).

In Nutshell, the reader is offered a limited narrative perspective of the yet unborn child. The term intense focalization, as defined by James, can be understood as "a 
preferable alternative to its predecessor-term, point of view" (James 10), and in the particular case of Nutshell, it becomes associated with the prenatal perspective of the narrator. Therefore, the tight and enclosed space is narrowed and determined merely by the baby's imagination based on what he mainly hears and perceives other than visual senses. He can perceive the bodily functions of his mother, becomes affected by her emotions, blood pressure and her physical condition. More specifically, his mood and his feelings change sometimes rather involuntarily according to the amount of alcohol in his and his mother's veins, which, as for the mother's behaviour, seems irresponsible, or in the extreme measure, a sign of her moral perversion. Hence, moral questions arise not only in the speech analysis of the mother and her lover, who are involved in the murderous plot against the baby's father, but the way she treats the child is careless from the start in every stage of her pregnancy. What is in question and what causes the "little Hamlet's" main dilemma is his right for existence since he does not seem to be in the position of a wanted child. However, his attempts to kill himself in the mother's womb is rather desperate, as well as his striving to be born prematurely. There is no doubt he will witness his father's murder even before he is born, as the space of the womb holds him tight. Even the option of preventing the murder seems hopeless. The only thing he can announce is his mere existence which is, however, rather uncertain and depends on his mother's will to let him live on and be born. McEwan's recent spatial experiment in Nutshell seems to be based on the author's most cruel intention to change the space concept of the baby's safe and at first very comfortable place in the nearest proximity of the mother inside her body into a place of horror and a prison-like cell from where there is no escape. There is also the psychological development of the baby's mind as he matures with every successive phase of the mother's pregnancy. However, this is not the only way for his physical and mental development. He gains experience with the knowledge of the murderous plot against his father, learns more details of the crime arrangements, and the dramatic tension of the narrative is intensified not only by the approaching date of his birth but also by the upcoming act of murder. As for the narrative perspective of intense focalization, the baby's mind works rationally as if it were the reasoning of a young adult person, with a sense of humour, irony and bitterness of the prenatal life experience, metaphorically reflecting existential thoughts of Shakespeare's tragic hero. His instinctive feelings are related to the mother in the closest attachment which is rather ambivalent. However, in his physical and mental existence, he is imprisoned in the mother's body where he is merely able to overhear other people's dialogues, trying to intervene in vain. Thus, his dilemma of revenge and his ability to act become spatially limited, and therefore he has no option but to wait until he is born. As part of his emotional struggle he is driven by the love of his moth- 
er and he has to admit that he loves her unexceptionally regardless of any space for rational reasoning. In Nutshell, McEwan constructs the extraordinary mental world producing the so-called time-space compression (Harvey 1990, 284), in which spatial and temporal distances shrink in an extreme example. The amount of information the unborn child can grasp and absorb into his mind is another extreme paradox of the text, which may be interpreted as a result of the influence of media and globalization.

The establishment of the so-called spatial mentality is, according to Harvey, "prone to transformations" (Harvey 1985, 34). Its change reflects the attitudes of fictional characters towards space and their perception of the space which surrounds them. In Nutshell, McEwan's experiment of space perception relies on the experience of the yet unborn hero who creates a mental map of London out of the elements the character perceives without seeing anything of the outside world. This aspect of the spatial experiment may be seen as extremely unrealistic even if we consider the scientific development in the field of examining the mind of an unborn child.

\section{The Uncanny as a Part of the Postmodern Gothic}

Defining the Gothic aspects in postmodern fiction, one should consider the interaction of Gothic elements in the context of postmodern literature in general. Both Gothic and postmodern literature blurs the boundary between the real and the fictional, considering the sublime effect of terror, the atmosphere of gloom and suspense and taking into account the demonic aspects of the main characters of postmodern Gothic fiction. The sublime aspect further points out to the unrepresentable, including the subjectivity and a self-conscious narrator of the postmodern Gothic novels. The "Uncanny", as pointed out by Lucy Armitt, "unravels itself even in the act of being written/read, and in the process, appears to take on a life of its own" (Powell, Smith 78). Hence, the text of postmodern Gothic fiction becomes open to the multiplicity of meanings, in an uncanny affinity with the literary tradition of the postmodern and the Gothic, simultaneously.

Among the variety of space concepts of McEwan's novels, The Cement Garden, Saturday, and Nutshell reflect the focus on the theory of the Postmodern Gothic. In McEwan's novels, the uncanny seems to lurk from behind the corners of London houses and apartments, in the extreme example of Nutshell, the confined and ghostly atmosphere becomes unravelled first from the point before the main character is even born. McEwan structures the concepts of inner spaces of the house or home with the sense of the postmodern Gothic as something "unhomely", in correspondence with Nicholas Royle's theoretical concept of the uncanny: 
But the uncanny is not simply an experience of strangeness or alienation. More specifically, it is a peculiar commingling of the familiar and unfamiliar. It can take the form of something familiar unexpectedly arising in a strange and unfamiliar context, or of something strange and unfamiliar unexpectedly arising in a familiar context. It can consist in a sense of homeliness uprooted, the revelation of something unhomely at the heart of hearth and home. (Royle 1)

In The Cement Garden, the unhomely becomes closely associated with the vaguely described events in connection with the parents' either sudden death in the case of the father, or in the description of the mother's illness resulting in the process of her dying. The reaction of the adolescent narrator and his sisters can be analyzed as a reaction to the repressed moment of terror (as described by Steven Bruhm in Contemporary Gothic: why we need it), where the uncanny is associated with the traumatic experience of the loss of parents, and it reflects upon the inexpressible experience connected with the parents' death. The adolescents' reaction to the situation and their spontaneous behaviour is then perceived as a deviation from the social and moral norms. Nevertheless, such behaviour can also be understood as resulting from the want of "desires and objects that have been forbidden" (Hogle 263): "These unconscious desires center on the problem of a lost object, the most overriding basis of our need for the Gothic and almost everything else. That loss is usually material $[\ldots]$, but the materiality of that loss always has a psychological and symbolic dimension to it" (Hogle 263).

McEwan's critical point in The Cement Garden, which can be read as a social study of the characters' behaviour, stresses the lack of moral authorities and family values. In accordance with the idea of Fred Botting, this notion of space can be considered as a form of cultural exhaustion (Hogle 277-99). The dilapidated house on the outskirts, occupied only by four orphaned siblings, becomes a fragmentary world, a cultural desert that symbolically reflects the loss of meaning in human lives of the postmodern era.

In The Comfort of Strangers, the concept of the city resembles a labyrinth of anonymous streets, reflecting the boredom and intellectual crisis of the main characters. The title of the novel becomes strangely ambiguous as the strangers in the city, the two main protagonists, are comforted first in death. In The Uncanny, Nicholas Royle mentions the theory of the death drive, which, according to Jonathan Dollimore (Death, Desire and Loss in Western Culture), becomes "life's driving force, its animating, dynamic principle" (Royle 85). As Royle claims further, the theoretical approach to the death drive had been stated in Freud's essay "The Uncanny" in 1919, without being mentioned explicitly. The death drive works in silence, Royle states (Royle 86), in correspondence with the general approach to the theoretical concept of the uncanny. It is "demonic, diabolical" (Royle, 88) and "eerily uncanny." In The Comfort of Strangers, the characters seem to be driven into 
death within the principle of the death drive, surrounded by the uncanny presence of the city. Their human existence ends up in silence, in a vortex of meaningless violence which contributes to the postmodern theory of the uncanny and corresponds with the absurdity of human actions in the contemporary civilization.

In correspondence with McEwan's omnipresent sarcasm underlying the title of the novel, the characters ramble around the city in lethargy, spending the days half asleep as if they were numb, in a state of paralysis and sensual crisis. The author's concept of space in The Comfort of Strangers, in which the city contradicts its image of an ideal tourist destination that should bring a particular excitement to the senses, reflects Lyotard postmodern theory of unpresentability: "[...] modern aesthetics is an aesthetic of the sublime, though a nostalgic one. It allows the unpresentable to be put forward only as the missing contents; but the form, because of its recognizable consistency, continues to offer the reader or viewer matter for solace and pleasure" (Lyotard 340).

In the sense of the postmodern cultural fragmentation and plurality (Botting 113), the city in The Comfort of Strangers can be perceived as an empty space. It remains anonymous as well as universal, it loses its proper name and the structure of the plot of the novel is hardly based on events, in correspondence with the postmodern theory (Slocombe 65). The plot becomes uneventful in a peculiar cycle of the characters' boredom until the climax in which the couple experiences a sublime moment before their death, in the hope that "something will happen, despite everything, within this threatening void, that something will take place and will announce that everything is not over" (Slocombe 65). In the novel's conclusion, the overwhelming motif of meaningless violence and exaggerated brutality reminds the reader of the postmodern crisis of humanity, and the presence of the uncanny that merely lurked from behind the scene becomes clearly revealed.

In The Contemporary Gothic, Stephen Bruhm states that Postmodern Gothic focuses on the experience of shock and trauma in a blend of fear and desire (Hogle 268). In her theoretical approach to the presentation of the modern theories of the sublime, Kamila Vrankova expands this notion further:

Dealing with the experience of shock or trauma, the postmodern concepts of the sublime draw on a paradoxical desire to speak about what cannot be uttered in words. In this respect, the sublime is a protest against the notion of silence as nothingness, or indifference. Corresponding with the inexpressible as an urgent presence of something (instead of nothing), it is associated with what cannot be spoken and cannot remain in silence at the same time." (Vrankova, 2018, 5) 
The experience of shock or trauma resulting in silence is a moment which permeates the lives of the majority of characters of the aforementioned novels. The extreme and grotesque example of a similar trauma can be traced in Nutshell. The yet unborn hero confronts the existential question whether his life will be worth it, as he contemplates in his private prison cell of the mother's womb, in the confined Gothic space which in a way resembles a coffin. Creating an intensively morbid image of someone being buried alive, through the hero's limited ability to move or act, McEwan makes use of the omnipresent sense of the macabre, alluding not only to Shakespeare's tragedy but also to his early novels. The yet unnamed hero of Nutshell faces an existential crisis of Hamlet unborn. In correspondence with Royle's notion of the Uncanny, in Nutshell, the sense of one's self is strangely questionable, the hero is surrounded by the feeling of uncertainty in the presence of something weird and mysterious that is being experienced (Royle 1) as a part of a metafictional play upon the reader and the Shakespearean characters within the play.

\section{Conclusion}

In the dynamic development of his space concepts, McEwan works with the category of the literary uncanny as the most frequent spatial practice. In connection with the theme of anxiety of space violation and ignorance of individual privacy, the characters/ victims of the novel Saturday, Amsterdam and Atonement should be mentioned. They are victims of the uncanny in the Freudian sense since they suffer from intellectual uncertainty and the reader's feeling of the presence of the uncanny approaches the real uncanny experience. McEwan's literary works rely on the presence of the uncanny through the depiction of the environment that seems to be familiar in its detailed description but lurking behind the scene there is the sense of the unexpected, unfamiliar and unhomely that should be anticipated at all times. The interrelationship between the protagonist and his spatial surroundings allows the existence of the uncanny in McEwan's novels as a spatial phenomenon. In The Comfort of Strangers, the urban labyrinth of a holiday resort forms the architecture of the uncanny as the plot twists from a boring ramble through the city into the brutal and unexpected final scene. The general use of darkness which hides potential criminal assaults becomes characteristic for Atonement and Saturday, spying in the dark forms the uncanny element in Sweet Tooth and The Innocent.

The limitations of McEwan's space concepts reflect upon the closed spaces as they occur in the works of Gothic fiction. Extreme examples of isolation or imprisonment in a confined space frame the space concepts of McEwan's first novel, The 
Cement Garden, and Nutshell, one of McEwan's latest works. In Nutshell, the reader is offered an insight into a spiritual space of the Hamlet yet unborn. The mental space of the child becomes a paradoxical distortion of Shakespeare's metaphor of the king of infinite space through interior monologues which allow the child a premature encounter with the truth of the outside world.

Considering the development and the dynamics of McEwan's space concepts, they seem to include a relatively narrow scope of fictional settings, both urban and rural. As for the images of the English countryside which appear in the short novel On Chesil Beach, or in episodic settings of Sweet Tooth and Amsterdam, the author makes use of traditional realistic techniques of natural descriptions in an evocation of a particular lyrical mood which corresponds with the feelings of characters on the scene. The author's major interest, however, centers in urban settings that reflect human alienation, isolation of individuals and existential crisis. As a result of intense focalization, McEwan's London is to some extent a mere mental space, mainly in his novels The Cement Garden or Nutshell. On the other hand, it is understood as a global metropolis in Saturday, similarly to McEwan's other novels (Amsterdam, Solar, Sweet Tooth). Both the private space of the individual and the global cityscape become united by the theme of space violation, the ignorance of privacy and the presence of the uncanny in the majority of McEwan's works.

From the most private space in Nutshell, intimate spaces in On Chesil Beach or The Cement Garden, McEwan proceeds to the globalized world in Amsterdam, Saturday and Solar. His characters are being watched, followed and spied on in the author's focus on the combination of the character's professional and private sphere of life in his contemporary works.

McEwan's focus on intense focalization and the presence of the uncanny contribute to further studies of the spatial dynamics of his works. The themes of breaking social conventions and the occurrence of taboo topics in his novels underlined by the omnipresent sense of the grotesque seem to reflect an unlimited variety of ideas and interpretations of both the fictional and real world.

\section{Works Cited}

Botting, Fred. 2004. Gothic. London and New York: Routledge. https://doi.org/10.4324/9780203993767

Bradford, Richard. 2007. The Novel Now. Contemporary British Fiction. Oxford: Blackwell Publishing. 
Childs, Peter. 2006. The Fiction of Ian McEwan. New York: Palgrave Macmillan. https://doi.org/10.1007/978-0-230-21127-8

Foucault, Michel. 1984. "Of Other Spaces: Utopias and Heterotopias.” Translated by Jay Miskowiec. Architecture /Mouvement/ Continuité 5: 46-49.

Groes, Sebastian. 2009. Ian McEwan: Contemporary Critical Perspectives. London: Bloomsbury Academic.

Harvey, David. 1990. The Condition of Postmodernity: An Enquiry into the Origins of Cultural Change. Oxford: Blackwell.

Harvey, David. 1994. "The Social Construction of Space and Time." Geographical Review of Japan. 67.2: 126-135. https://doi.org/10.4157/grj1984b.67.126

Harvey, David. 1985. Consciousness and the Urban Experience: Studies in the History and Theory of Capitalist Urbanization. Baltimore: The Johns Hopkins University Press.

Head, Dominic. 2002. The Cambridge Introduction to Modern British Fiction, 1950-2000. Cambridge: Cambridge University Press. https://doi.org/10.1017/ CBO9780511606199

Hogle, Jerrold E.. 2012. The Cambridge Companion to Gothic Fiction. Cambridge: Cambridge University Press.

James, David. 2008. Contemporary British Fiction and the Artistry of Space: Style, Landscape, Perception. London and New York: Continuum.

Lefebvre, Henri. 1984. The Production of Space. Translated by Donald Nicholson-Smith. Oxford: Blackwell, 1974.

Lyotard, Jean-Francois. 1984. The Postmodern Condition: A Report on Knowledge. Trans. Geoffrey Bennington and Brian Massumi. Manchester: Manchester University Press. https://doi.org/10.2307/1772278

Malcolm, David. 2002. Understanding Ian McEwan. Columbia: University of South Carolina Press.

McEwan, Ian. 1998. Amsterdam. London: Jonathan Cape.

McEwan, Ian. 2016. Nutshell. London: Jonathan Cape. 
McEwan, Ian. 2007. On Chesil Beach. London: Jonathan Cape.

McEwan, Ian. 2012. Sweet Tooth. London: Jonathan Cape.

Pleßke, Nora. 2014. The Intelligible Metropolis: Urban Mentality in Contemporary London Novels. Bielefeld: Transcript Verlag. https://doi.org/10.14361/transcript.9783839426722

Powell, Anna. 2006. Teaching the Gothic. New York: Palgrave Macmillan. https://doi.org/10.1057/9780230625358

Royle, Nicholas. 2003. The Uncanny. Manchester: Manchester University Press.

Slocombe, William. 2006. Nibilism and the Sublime Postmodern. New York: Routledge.

Smethurst, Paul. 2000. The Postmodern Chronotope: Reading Space and Time in Contemporary Fiction. Amsterdam Atlanta: Rodopi.

Tew, Philip. 2016. "Exploring London in Ian McEwan's Saturday (2005): Trauma and the Traumatological, Identity Politics and Vicarious Victimhood." In London in Contemporary British Fiction: The City beyond the City, edited by Nick Hubble and Philip Tew, 17-33. London: Bloomsbury Academics.

Tew, Philip. 2007. The Contemporary British Novel. London: Continuum.

Vránková, Kamila. 2019. Metamorphoses of the Sublime: From Ballads and Gothic Novels to Contemporary Anglo-American Children's Literature. České Budějovice: Pedagogická fakulta JU.

Vránková, Kamila. 2018. "Modern Theories of the Sublime: The Question of Presentation." Eger Journal of English StudiesXVIII: 3-15. https://doi.org/10.33035/ EgerJES.2018.18.3

Zoran, Gabriel. 1984. “Towards a Theory of Space Narrative." Poetics Today. The Construction of Reality in Fiction 5 (2): 309-335. https://doi.org/10.2307/1771935 